\title{
Understanding Trade-offs in the Supplier Selection Process: The Role of Flexibility, Delivery, and Value-added Services/Support
}

\author{
Bo van der Rhee ${ }^{1}$ \\ Rohit Verma ${ }^{2}$ \\ Gerhard Plaschka ${ }^{3}$
}

In this study, we present, based on econometric choice modeling framework, how manufacturing managers/executives trade-off between cost, delivery, flexibility, and service features in the supplier selection process for commodity raw materials, given acceptable quality. Empirical data for this study was collected from manufacturing organizations in Europe (Germany, France, Italy, and UK) using a computer-based supplier selection discrete choice survey. Each survey instrument contained 16 supplier selection choice sets, which compared 23 attributes of the current suppliers with a "new" potential supplier. The attributes of new suppliers were varied across two to four levels using established factorial experimental design procedures. The resultant multinomial logit models show the relative impact of cost, flexibility, delivery and service features on supplier selection.

\section{Introduction}

Over the last thirty years, supply chain management (SCM) and the supplier selection processes have received considerable attention in the operations management literature (Miller et al., 1981). Several scholars have emphasized the multi-disciplinary nature of supply chains and suggested that the use of economics and marketing- based methods can further increase the effectiveness of SCM (e.g. Bankar and Khoska, 1995; Karmarkar, 1996). For example, as outsourcing becomes more important in many industries, the supplier selection process does as well (Kannan and Tan, 2002; Yan et al., 2003; Choy et al., 2003, 2004; Li et al., 2006). In addition, with the rapid proliferation of information sharing across supply chains, the importance of supplier management has been amplified during recent years (e.g. Fine, 1998;

\footnotetext{
${ }^{1}$ Cluster Marketing \& Supply Chain Management, Nyenrode Business University, Straatweg 25, P.O. Box 130, 3620 AC Breukelen, The Netherlands

${ }^{2}$ Service Operations Management, School of Hotel Administration, Cornell University, Ithaca, NY 14853, USA

${ }^{3}$ Department of Management, DePaul University, Chicago, IL, USA
} 
Hanfield and Nichols, 1999; Kaplan and Sawhney, 2000; Simchi-Levi et al., 2000; Hall and Braithwaite, 2001). A number of empirical studies also show that managers indeed con- sider the role of the supplier to be critical for superior business performance (e.g. Flynn et al., 1994; Choi and Hartley, 1996; Vonderembse and Tracey, 1999; Gonzalez et al., 2004).

While the academic literature is very comprehensive, the effective evaluation and selection of suppliers for important raw materials continues to be challenging in many industries. In this context, the past research shows that firms use price and a number of other dimensions such as quality, flexibility, delivery, and service in the supplier selection process (e.g. Dickson, 1966; Hirakubo and Kublin, 1998; Li et al., 2006; Sarkis and Talluri, 2002; Verma and Pullman, 1998; Wilson, 1994). Broadly speaking, supplier selection trade-offs correspond well with various competitive priorities identified by and explored extensively in the operations strategy research (e.g. Hayes and Wheelwright, 1984; Boyer and Lewis, 2002).

The supplier selection literature is also rich in terms of conceptual models, decision support systems, simulation studies, and empirical analyses related to the vendor evaluation (e.g. Pearn et al., 2004; Bhutta and Huq, 2002; Chan, 2003; Chan and Chan 2004; Onesime et al., 2004; Basnet and Leung, 2005; Valluri and Croson, 2005; Carter and Jennings, 2004; Kamann and Bakker, 2004; Lin et al., 2005). However, relatively little work has been done to integrate market utility-based approaches in the supplier selection processes as recommended by both classic and contemporary research in operations strategy (e.g Anderson et al., 1989; Vickery et al., 1993; Boyer et al., 1996).

Market utility-based approaches such as discrete choice analysis (DCA) (also know as choice-based con- joint) can assess the relative weights of price, quality, delivery, flexibility, and various value-added features in various managerial decision-making processes (e.g. Ben-Akiva and Lerman, 1991; McFadden, 1986; Louviere et al., 2001). These methods have seen wide applications in many social sciences including marketing, transportation planning, environmental resource economics, service design, and operations management (e.g. Green and Krieger, 1996; Pullman and Moore, 1999; Pullman et al., 2001; Verma et al., 2001). Examples of discrete choice and conjoint analysis in operations management include product line decisions (e.g., Yano and Dobson, 1998); optimal service design (Verma et al., 2001); and operations capacity planning (Pullman and Moore, 1999). In addition, Ding et al. (2007), and Victorino et al. (2005) have applied discrete choice models in a variety of operational settings. Furthermore, an emerging emphasis on incorporating behavioral aspects into manufacturing and service operations models (Bendoly et al., 2006), portends future growth of DCA and related approaches in the operations management literature.

As mentioned earlier, despite its advantages, DCA has only been used in a few papers related to supplier selection. Specifically, Verma and Pullman (1998) presented a simple illustration of DCA for supplier selection. They demonstrated that the managers' perceived importance of supplier attributes such as quality, cost, delivery, and flexibility are not consistent with their actual choices. Li et al. (2006) extended the use of DCA in supplier 
selection literature by comparing the attributes of an existing supplier to that of a new supplier. They also extended the theoretical framework to include supplier switching inertia. Our paper adds to the above stream of evolving literature on the use of DCA in the supplier selection process.

In this paper, we explore how executives trade-off amongst various competitive dimensions when selecting a supplier for important but commodity raw materials. The empirical context of our study is based on a commodity (aluminum profiles used in a variety of manufacturing industries) where quality is assessed as "conforming to specifications" and therefore is a necessary requirement or order qualifier for competing but is not an order winner. Based on literature review, it is our impression that supplier selection of such context has not been studied in detail before.

Hence, in this experimental empirical study (details provided later) we assess the managerial trade-offs for cost, delivery performance, flexibility, and value-added service/support in a supplier selection process using a market utility-based approach (DCA). Specifically, we address the following research issues:

Research Objective 1: How do managers trade-off between price and other competitive dimensions when choosing a supplier for commodity raw materials, given acceptable quality?

Research Objective 2: What is the relative importance of value-added service and support when choosing a supplier for commodity raw materials, given acceptable quality?

Similar research questions have been addressed in past research. However, as mentioned earlier, with the exception of two papers, a market utility-based approach has not been used to assess trade-offs in the supplier selection process. Our study also demonstrates a new approach for DCA suggested by Li et al. (2006), which allows us to compare potential new suppliers with the existing supplier, thereby isolating the associated trade-offs accurately.

Furthermore, in today's business environment with the possibility to source raw materials from almost anywhere in the world, it is possible that cultural/national differ-ences exist with-respect-to supplier evaluation and assessment (e.g. Hofstede, 2003; Schroeder and Flynn, 2001). Therefore after conducting the primary study in one country (Germany) we collected small samples of additional data from three other countries in Europe (UK, France, Italy). The supplementary dataset will also use to explore the following research issue:

Research Objective 3: How do trade-offs in the supplier selection process differ across cultural/national regions?

The rest of the manuscript is structured as follows: first, we review past research in supplier selection analysis. Second, we describe the research design including an overview of 
the DCA followed by the results of an empirical study conducted in four languages in Europe. Finally, we discuss the research and managerial implications of our work.

\section{Literature Review}

In one of the early studies based on empirical data collected from 170 purchasing managers, members of the National Association of PurchasingManagers, Dickson (1966) identified over 20 attributes which managers generally consider when choosing a supplier. Following this exploratory study, a great number of articles focused on SCM and supplier selection criteria specifically. We discuss a number of these articles in this section, starting with the conceptual and review papers, followed by empirical research, decision support system papers, simulation studies, and finally supplier evaluation and selection modeling papers.

\section{Conceptual and Review Papers}

A number of conceptual papers have been published in the last decades that emphasized the strategic importance of the supplier selection process and evaluated the relative importance of quality, cost, delivery performance, and other supplier attributes in the supplier selection process (e.g., Cardozo and Cagley, 1971; Sheth, 1973; Dempsey, 1978; Ansari and Modarress, 1980, 1986; Monczka et al., 1981; Hahn et al., 1983; Jackson, 1983; Kraljic, 1983; Browning et al., 1983; Treleven, 1987; Burton, 1988; Bernard, 1989; Wagner et al., 1989; Benton and Krajewski, 1990; Chapman, 1993). The interested reader is referred to a handbook of logistics and SCM (Brewer et al., 2001) or Weber et al. (1991) for a general overview of the supplier selection literature.

\section{Empirical Research}

During recent years a number of empirical articles have been published which address supplier selection issues in specific industries and/or present a comparison between two or more industries. For example, Mummalaneni and Dubas (1996) presented the results of an exploratory study examining the trade-offs made by Chinese purchasing managers among six performance measurement attributes. Pearson and Ellram (1995) examined supplier selection and evaluation criteria in small and large electronic firms in the US. Swift (1995) presented criteria used by purchasing managers in selecting single suppliers. Lambert and Adams (1997) presented an empirical review of attributes traditionally used by purchasing managers in supplier selection in the hospital setting. Hirakubo and Kublin (1998) examined the purchasing behavior in he electronics components industry in Japan. Robb et al. (2008) focus on manufacturing strategies in China, and Amoako-Gyampah and Acquaah (2008) in Ghana.

Patton (1997) addressed trade-offs in individual and joint selection decision-making in the industrial supplier selection process. Ittner and Larcker (1999) examined the relationship between supplier selection, monitoring practices, and organizational performance, while Liao and Rittscher (2007b) develop a multi-objective programming model which includes a supplier selection component. Carter and Jennings (2004) studied corporate social responsibility in the 
purchasing function context. Lin et al. (2005) showed that quality management practices are significantly correlated with supplier selection strategies. And finally, Gonzalez et al. (2004) investigated the importance of supplier selection in the quality of the final product and determined that it is in fact the most significant variable.

\section{Decision Support System Papers}

Most often a manufacturer has multiple suppliers to choose from and has to make a decision based on multiple variables. To accommodate this decision, Weber and Current (1993) proposed a multi-objective approach to supplier selection which provides a useful decision support system for a purchasing manager faced with multiple suppliers and trade-offs such as price, delivery reliability, and product quality. Alternatively, Pearn et al. (2004) developed a process capability index $\left(C_{p m}\right)$ which collapses all the decision variables into a single index, which simplifies the supplier decision, while Huang and Keskar (2007) provide a supplier selection method which takes into account the firm's business strategy.

Perhaps the most used decision support system for supplier selection is the analytical hierarchy process (AHP). An application of the AHP to the supplier selection process was first described by Barbarosoglu and Yazgac (1997), and it has subsequently been compared with the total cost of ownership (TCO) method (Bhutta and Huq, 2002), applied on vendor selection (Chan, 2003), used to tackle multi-item/person/criterion decisions (Chan, 2004) and used along with the gray rational scale by Tseng and Lin (2005) to rate suppliers. Talluri et al. (2006) proposed an integration of the TCO and the AHP approaches for selecting appropriate suppliers. Also, Wang et al. (2004) use a combination of AHP and preemptive goal programming (PGP) to both qualitatively determine which supplier to use and mathematically determine the optimal order quantity from the chosen supplier.

In addition to combining the AHP approach with other methods, Chan and Kumar (2007) extended it by including risk factors involved in global supplier selection. Their fuzzy extended analytic hierarchy process (FEAHP) is an efficient tool to handle the fuzziness of the data involved in deciding the preferences of different decision variables. Chen et al. (2006) also employed a hierarchical model using triangular fuzzy numbers to deal with supplier selection problems.

\section{Simulation Studies}

A number of simulation studies with a focus on the supplier selection process have also been published. For example, Crama et al. (2004) formulated a non-linear 0-1 programming problem with complex quantity discounts offered by different suppliers and alternative product recipes. Cakravastia and Takahashi (2004) created a simulation model to determine which supplier to select for business and the volume assigned to each of those suppliers. Finally, Basnet and Leung (2005) created a simulation model to determine what products to order in which quantities from which supplier in which periods to satisfy a given demand stream. 


\section{Suppliers Evaluation and Selection Modeling Papers}

It is desirable for firms to select a supplier that excels in most of the supplier evaluation criteria. At the same time, it is unlikely that any one supplier can excel in all or multiple evaluation criteria at a reasonable cost. Consequently firms have to trade-off between price, quality, and other value-added features when choosing suppliers for key components and raw materials. To address this complex multi-criteria managerial decision-making problem, a variety of supplier evaluation and selection models have been developed. For example, Vokurka and Choobineh (1996) developed a prototype expert system for evaluation and selection of potential suppliers. Patton (1996) explored the impact of human judgment models in combination with multi-attribute supplier evaluation methods. Rosenthal and Zydiak (1995) and Sarkis and Semple (1999) addressed the issue of bundling multiple stock items on purchase costs and subsequently on supplier selection. Karpak et al. (1999) presented a visual interactive goal programming procedure that assists purchasing teams in the supplier selection process. Petroni and Braglia (2000) proposed an alternative decision model based on purchasing managers' periodic evaluation of the supplier using a principle components analysis. Masella and Rangone (2000) proposed a contingency approach for supplier selection depending on the time frame and the content of co-operative customer/ supplier relationships, while Prahinski and Benton (2004) investigated how suppliers perceive the buying firm's supplier evaluation communication process and what its impact is on the suppliers' performance, and Araz and Ozkarahan (2007) focus on the long-term effects in selecting suppliers.

Eltantawy et al. (2003) and Sharland et al. (2003) both examined the role of cycle time to supplier selection and performance. Braglia (2000) developed a data envelopment analysisbased model for formulating sourcing strategies in changing marketplace. Degraeve et al. (2005) proposed a mathematical programming approach known as TCO perspective which allegedly outperforms other multi-criteria supplier selection models and combined this later with activity-based costing (Roodhooft and Konings, 1997) in a case study.

In summary, without claiming that we have presented an exhaustive list of references in the above, it is evident that the supplier selection literature boasts an abundance of conceptual and review, empirical research, decision support systems, simulation studies, and applications of multi-criteria decision-making technique papers. We contribute to this stream of research by illustrating the usefulness of DCA in evaluating the relative impact of various value-added features in the supplier selection process in a multinational environment.

\section{Research Methods}

To explore the research objectives listed earlier, we designed a computerized experimental supplier selection study using DCA. The respondent population consisted of manufacturing companies located in four European countries - Germany, UK, France, and Italy. The primary sample was obtained from Germany where larger num- bers of manufacturing 
firms were the users of aluminum profiles as raw materials. Secondary samples were obtained from the other three countries for the purpose of cross-cultural comparisons.

The list of the manufacturing companies was obtained from a European trade association of business-to-business (B2B) firms which use aluminum as the primary raw material in their manufacturing processes. Since there are generally accepted industry guidelines for metals, the "quality" is considered an order qualifier rather than an order winner when selecting a supplier for commodities (e.g., aluminum which does not meet industry criteria is simply rejected). Furthermore, aluminum is used as a primary raw material for companies that manufacture a variety of products in a wide rage of industries, and therefore their supply represents an ideal empirical context for our purposes. The reader should note that we verified the industry practice by interviewing a number of executive and industry leaders across many different firms (additional details about data collection is provided later in this paper).

\section{Approach}

In order to understand the trade-offs in the supplier selection process, one needs to consider the relative weights that buyers attach to various characteristics of their current supplier with respect to other competitors. When faced with a supplier selection choice task, decision-makers (purchasing managers and executives) are likely to consider features/characteristics of their current suppliers that they are already familiar with and also new features/characteristics that are made available to them by potential suppliers (Bettman et al., 1975; Lancaster, 1966; Lynch et al., 1988). At the same time, it is generally not possible for any supplier to excel in all criteria considered by the buyer at the best possible price (e.g., Li et al., 2006). Therefore, the buyer has to make trade-offs when faced with a choice between staying with the existing supplier and switching to a new supplier. Hence we used DCA which is an effective method for determining the relative weights assigned by decision- makers to components of decision criteria (Ben-Akiva and Lerman, 1991; Louviere andWoodworth, 1983; McFadden, 1986).

DCA provides a systematic way to identify the implied relative weights and trade-offs revealed by the choices of decision-makers (e.g., a purchasing executive). DCA has been used to model choice behavior in many business and social science fields, and introductions to and extensions of DCA can be found in sources cited above and others such as McFadden (1986), Hensher and Johnson (1981), Green and Krieger (1996), and Guadagni and Little (1983). Econometric models developed from a DCA study can link determinant supplier attributes to decision-makers' (e.g., buyer) preferences. Therefore, by describing a supplier in terms of appropriate attributes, DCA can be used to predict market impact of competitors in a given environment. In particular, research suggests that after acquiring information and learning about possible alter- natives (e.g., current and new potential suppliers), decision-makers define a set of determinant attributes to use to compare and evaluate alternatives. They then form impressions of each alternatives' position on the determinant attributes, value these attribute 
positions vis-à -vis one another (i.e., make trade-offs), and combine the attribute information to form overall impressions of each alternative.

It is now well known that within the discrete choice framework the conditional probability of choosing an alternative in a choice set can be expressed as a multinomial logit (MNL) model (McFadden, 1986). Execution of DCA requires careful design of product/service profiles (e.g., a specific supplier of aluminum) and choice sets (e.g., a group of potential suppliers) in which two or more alternatives are offered to decision-makers (e.g., buyers), and they are asked to evaluate the options and choose one (or none). Each respondent in a DCA experiment receives several choice sets to evaluate (e.g., 8-32 sets) with two or more hypothetical services to choose from in each set. The design of the experiment is under the control of the researcher, and consequently, the decision-makers' choices (dependent variable) are a function of the attributes of each alternative, personal characteristics of the respondents, and unobserved effects captured by the random component (i.e., unobserved heterogeneity or omitted factors) (Louviere and Woodworth, 1983; Verma et al., 1999).

DCA applications based on choice experiments typically involve the following steps: (1) identification of determinant attributes, (2) specification of attribute levels, (3) experimental design, (4) presentation of alternatives to respondents, and (5) estimation of the choice model. Past studies have shown that in general the market predictions generated from the statistical models based on DCA are extremely accurate (e.g., Verma et al., 2008).

\section{Experimental Supplier Attributes}

Louviere et al. (2000) suggest that one should consider the following when building a list of attributes for discrete choice experimental design: (1) Is it necessary to include an exhaustive list of all salient attributes? (2) Which attributes can be retained, recombined, or re-expressed to keep the set of attributes as non-redundant and as small as possible to make the experiment tractable but realistic? They suggest that great care must be taken to ensure that all (or at least as many as possible) of the determinant decision attributes are identified and expressed in terms understood by the decision-makers to be studied. They recommend use of qualitative surveys, interviews, case studies, and/or focus groups to identify a set of relevant attributes along with reviews of practitioner and academic literatures.

In order to develop a comprehensive list of aluminum supplier attributes, we first collected in-depth qualitative information from plant level and corporate senior execu- tives of both buyer and supplier organizations responsible for supply chain purchasing, production and corporate responsibilities. We conducted a number of interviews and group discussion sessions in addition to reviewing both academic and practitioners' literature related to the topic. These qualitative focus groups and interviews were conducted across four European countries (Germany, UK, France, and Italy) in local languages.

Based on information collected during the qualitative research phase described above, we developed an initial list of supplier attributes and their levels. This list was distributed to all 
the executives and also to some new executives for additional feedback and edits. Based on their responses the list of attributes was modified for content, wording, and comprehensiveness. After four similar iterations the final list of supplier attributes/levels was considered acceptable by most executives and by members of our research team.

Table1 lists selected supplier attributes, their levels, and their classification into four broad conceptual categories (cost, delivery performance, value-added service/ support, and flexibility).The value-added service/support category was further subdivided into two subgroups: services - which was comprised of three attributes (problem-solving services, online ordering service, and assembly service) and support - which was comprised of four attributes (supplier's experience with different types of aluminum alloys, flexibility in manufacturing standards, manufacturing tolerances, and flexibility in providing additional manufacturing capabilities), demand flexibility - which consisted of four attributes (ability to rush orders, get small land large size orders, change annual demand, and flexibility in order proposal submission), and variety-which was also comprised of four attributes (type of packaging, format of packaging, type of products offered, and range within each type of product offering). See for example also Liao and Rittscher (2007a), who focused specifically on the issue of supplier flexibility. The delivery performance category included three attributes (speed of prototype delivery, lead time, and variability in on-time delivery performance) and cost included only one attribute-price. Table1 lists the conceptual categories, and attributes used in the study.

\begin{tabular}{|c|c|c|c|c|c|c|}
\hline \multicolumn{3}{|l|}{ Flexibility } & \multicolumn{2}{|l|}{ Value added } & \multirow{2}{*}{$\begin{array}{l}\text { Delivery } \\
\text { performance } \\
\text { Speed }\end{array}$} & \multirow[t]{2}{*}{ Cost } \\
\hline Production & Demand & Variety & Support & Services & & \\
\hline Experience with alloy (2) & $\begin{array}{l}\text { Rush orders } \\
\text { (2) }\end{array}$ & $\begin{array}{l}\text { Packaging } \\
\text { type (2) }\end{array}$ & Risk mgt (2) & Problem solving (4) & $\begin{array}{l}\text { Prototype } \\
\text { delivery (4) }\end{array}$ & Price (4) \\
\hline Standards and guidelines (2) & $\begin{array}{l}\text { Small } \\
\text { orders (2) }\end{array}$ & $\begin{array}{l}\text { Packaging } \\
\text { format (4) }\end{array}$ & Inventory mgt (2) & $\begin{array}{l}\text { Assembling } \\
\text { services (3) }\end{array}$ & Lead time (4) & \\
\hline Manufacturing tolerances (2) & $\begin{array}{l}\text { Adj. annual } \\
\text { demand (4) }\end{array}$ & $\begin{array}{l}\text { Type of } \\
\text { Products } \\
\text { (4) }\end{array}$ & $\begin{array}{l}\text { Engineering } \\
\text { consulting (4) }\end{array}$ & Online ordering ( 3 ) & $\begin{array}{l}\text { On time } \\
\text { delivery (4) }\end{array}$ & \\
\hline Machining flexibility (3) & $\begin{array}{l}\text { Proposal } \\
\text { process (4) }\end{array}$ & $\begin{array}{l}\text { Product } \\
\text { ranges (3) }\end{array}$ & Order tracking (4) & & & \\
\hline
\end{tabular}

Note: numbers in brackets indicates levels for each experimental attribute.

Table 1 Supplier choice experiment: constructs, attributes, and levels

To create realistic supplier choice experiments, two to four realistic levels for each of the 23 identified supplier attributes were identified. Again we used the guidelines established by the discrete choice methodology literature (e.g., Ben-Akiva and Lerman, 1991) when developing levels for the final list of experimental attributes. While the descriptions of levels of attributes are specific to the aluminum industry, the conceptual categories and most of the attributes described above are fairly general. There- fore, in this paper we predominantly limit the discussion to broad supplier selection categories and higher-level attributes. 


\section{Experimental Design}

As described in Table 1, a total of 23 experimental attributes, each with two to four levels, were identified after the qualitative research stage. As is common practice in DCA with large number of attributes, we used fractional factorial design procedure to develop 64 orthogonal supplier profiles, which could allow the estimation of main effects for all attributes (Louviere et al., 2000). To enhance the realism of the task, a full-profile approach was used in presenting the choice sets (Green and Srinivasan, 1990), i.e., each profile shown to the respondents simultaneously described some combination of all the attributes. The resulting 64 experimental supplier profiles were divided into four statistically equivalent sets of 16 profiles each, since evaluation of 64 profiles is too many for one respondent. Later each respondent was randomly assigned to one of the four sets and was asked to respond to 16 choice tasks as described below.

The supplier selection choice task was formulated as a comparison between a respondent's "current" supplier and an "alternative" supplier generated experimentally. To be able to implement such a choice task it was necessary to first ask the respondent to describe the levels for each experimental attribute for their "current" supplier. Note that the description of "current" supplier can be unique to each respondent. Therefore the resulting choice experiment was unique to each respondent. As mentioned briefly in the introduction section, this methodological advance (comparison of an experimentally designed new supplier with each respondent's current supplier) allows for the unique tailoring of the choice experiment to the respondents' unique decision-making situation.

Implementation of the "current" versus "new" supplier choice experiment then requires that we keep track of respondents' answers and then incorporate them within the choice experiment. Therefore we developed a data- base-driven survey system to keep track of each individual's responses about their current supplier and then later presented them alongside the experimentally generated "new" supplier profiles. Such an experiment could not have been conducted using a traditional paper and survey instrument. Therefore, the survey was done via computer so that each survey could be customized.

We pre-tested the choice experiment with the group of executives who participated in the qualitative research and also with 10 new respondents. Based on their feedback, the working and layout of the survey was slightly modified to enhance clarity and realism of the choice tasks. In addition to the supplier selection choice task, the survey instrument included demographic questions about the respondents (e.g., age, gender, education, and work experience) and background information about the respondents' organization.

\section{Data Collection}

The invitation to participate in the survey was sent to executives in approximately 350 manufacturing companies in four European countries (Germany, France, UK, and Italy) which buy and use aluminum as a raw material in their factories. The majority of the companies in the 
database were located in Germany (approximately 225), while the others were scattered across the remaining three countries. Senior executives with purchasing/ supplier selection responsibility, such as purchasing managers, plant managers, operations managers, VP for manufacturing/supply management (or similar), were contacted by phone and were requested to participate in the survey. The participants had the opportunity to obtain a copy of the summarized results and monetary incentives by participating in the survey.

After recruiting potential respondents by phone, we sent them access to the computerized survey in their own language (German, English, French, or Italian). Those respondents that did not answer the survey within the next two weeks were reminded by both phone and e-mail. The resulting response rate for all the executives who had agreed to participate in the survey was approximately $65 \%$. We would like to emphasize that the data collection for this project was quite expensive and a rather time- consuming process. In addition, the design and development of the individually customizable choice experiment (current vs. new supplier) required extensive programming. To check for a non-response bias we compared the responses of early and late responders. Since we only had contact information for the non-respondents we could not statistically compare the demographic characteristics of respondents to non-respondents. At the same time, the distribution of organizations and respondents is quite broad (based on several criteria such as size, geographical region, education, etc.) and therefore appropriate for the purposes of our study.

\section{Result and Analysis}

In this section we describe the data analysis and choice modeling results. We first provide a description of sample characteristics followed by analysis of supplier section choice exercises.

\section{Sample Characteristics}

Descriptive statistics about the respondent pool are summarized in Table 2. Of the 200 completed (after discarding incomplete surveys) responses, approximately $72 \%$ of respondents were from Germany, 9\% from the UK, 6\% from Italy, and 12\% from France. Ideally, we would have liked to get equal number of respondents from each of the four countries; however, the original database included the majority of listings from Germany, the source of our primary sample.

Furthermore, we did not find any evidence of response bias based on the country the respondent belonged to. Table 2 also shows the wide range of industries the respondents operate in. The two largest industrial sectors were transportation equipment manufacturing (23.5\% respondents) and industrial machinery and equipment manufacturing $(21.5 \%$ respondents) followed by electronic equipment manufacturing (15.5\%) and building components manufacturing (14\%). The remaining approx.. $30 \%$ of respondents were distributed across a various other industries which use aluminum as raw material. The job title 
of respondents varied and approximately $55 \%$ of the respondents were purchasing officer followed by plant engineer (11\%), plant or business unit manager $(8 \%)$.

\begin{tabular}{lr} 
Respondent's country & \\
Germany & $72.5 \%$ \\
United Kingdom & $6.5 \%$ \\
Italy & $9.0 \%$ \\
France & $12.0 \%$ \\
& \\
Respondents' job function & \\
Purchasing Officer & $54.5 \%$ \\
Plant Engineer & $11.0 \%$ \\
Plant or Business Unit Manager & $6.5 \%$ \\
Other (including no response) & $28.0 \%$ \\
& \\
Industry & \\
Building component manufacturing & $14.0 \%$ \\
Electronic equipment manufacturing & $15.5 \%$ \\
Heating, AC, sanitary and renewable energy equipment & $3.0 \%$ \\
manufacturing & \\
Household and office fixtures manufacturing & $6.0 \%$ \\
Industrial machinery and equipment manufacturing & $21.5 \%$ \\
Transportation equipment manufacturing & $23.5 \%$ \\
Other & $16.5 \%$ \\
& \\
Annual aluminum usage & \\
Less than 10t & \\
10-20t & $26.5 \%$ \\
$21-50 t$ & $20.0 \%$ \\
$51-100 t$ & $14.5 \%$ \\
101-1000t & $25.5 \%$ \\
More than 1000t & $5.5 \%$ \\
\hline
\end{tabular}

Total sample size $=200$.

Table 2 Sample characteristics

The annual usage of aluminum shows an interesting $U$-shape relationship as approximately a quarter of the firms use either less than $10 \mathrm{t}$ of aluminum (26.5\%) or between 100 and $1000 \mathrm{t}$ (25.5\%), while only $8 \%$ uses $20-50 \mathrm{t}$ of aluminum a year. When asked about how important aluminum raw materials were for their production processes, $57 \%$ of the respondents replied that it was a critical component (the remaining $43 \%$ checked on the box marked "used in production process but not critical"). About $90 \%$ of the respondents mentioned that the aluminum raw materials used in their production processes required some form of customization from the supplier. When asked where the buyers purchase their raw materials, approximately $50 \%$ replied that they get aluminum directly from the manufacturers of the components needed; approximately $30 \%$ purchased from general and specialized distributors; the remaining $20 \%$ were distributed amongst catalog/mail order supplier, internet- 
only supplier, local distributor/re-sellers and miscellaneous suppliers. The majority of the respondents (86.5\%) mentioned that they receive shipments of aluminum at least once/month.

\section{Supplier Choice Analysis}

The primary analysis approach associated with DCA is the estimation of the MNL models based on a maximum- likelihood estimation technique (equations (1) and (2)). We used the LIMDEP program to estimate three supplier selection MNL models: one for all the respondents (the complete model), one for only the German respondents, and one for the other three nonGerman countries from which data was collected. All of the estimated models were found to be statistically significant at the $5 \%$ level and the necessary goodness-of-fit measures (loglikelihood ratio; McFadden's $\rho^{2}$ ) show excellent statistical properties (Ben-Akiva and Lerman, 1991; Louviere et al., 2001). Similar to ordinary least square regression, MNL models are derived by estimating $\beta$ show excellent statistical properties (Ben-Akiva and Lerman, 1991; Louviere et al., 2001). Similar to ordinary least square regression, MNL models are derived by estimating ( $\mu$ in equation (1)) within each estimated model are different from each other because of differences in inherent variability within different samples. Therefore, as recommended by Swait and Louviere (1993), we re-scaled the models using a $\chi^{2}$ test-based procedure so that the estimated weights across models can be compared to each other. Hence, for the sake of clarity, the results in this paper are presented in easy-to-follow graphical and more descriptive format. Detailed statistical results are avail- able from the authors upon request.

\begin{tabular}{llll}
\hline Construct & Complete & $\begin{array}{l}\text { Only } \\
\text { German }\end{array}$ & $\begin{array}{l}\text { Only non-German } \\
\text { (English, French, } \\
\text { and Italian) }\end{array}$ \\
\hline Production flexibility & 1.6407 & 1.8763 & 1.0195 \\
Value-added support & 1.4463 & 1.6178 & 0.9942 \\
Variety flexibility & 1.3061 & 1.4621 & 0.8947 \\
Delivery performance & 1.1628 & 1.2942 & 0.8165 \\
Demand flexibility & 1.0564 & 1.1767 & 0.7393 \\
Value-added services & 0.9478 & 1.1212 & 0.4905 \\
Cost & $\mathbf{0 . 7 2 6 5}$ & $\mathbf{0 . 6 5 9 3}$ & $\mathbf{0 . 9 0 3 7}$ \\
\hline
\end{tabular}

Table 3 The seven main effects for the three estimated supplier selection choice models in decreasing importance

Recall from Table 1 that we identified four conceptual categories (cost, delivery performance, value-added service/support, and flexibility), each with one or more subgroups, which in turn consisted of multiple attributes. Table 3 shows the main effects for the seven subgroups in decreasing importance, while Fig. 1 shows these seven in a pie chart and grouped by the four conceptual constructs. The relative sizes of the fractions represents the value of each of the seven subgroups and are derived from the main effects of the constituent attributes 
(the main effects of all attributes included within each constructs were added together to get the composite score for each subgroup).

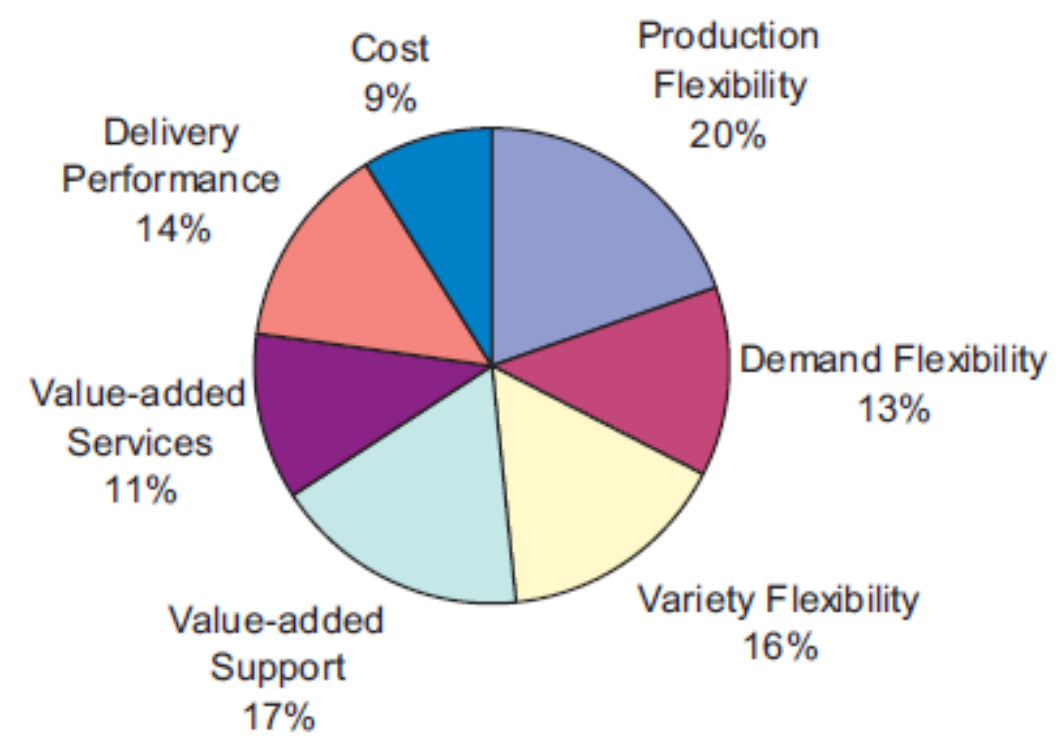

Fig. 1 The flexibility constructs' main effects make up almost half of the total input

The most interesting observation with regards to our third research objective (international differences) can be found in Table 3: even though the cost is the least important out of the seven subgroups, it is also the only construct to which the non-Germans attach a higher importance than the Germans. Furthermore, Fig. 1 shows that overall the respondents almost attach as much weight to the flexibility category as to all the other categories combined.

Fig. 2 shows the differences between the German and the non-German respondents for the attributes in four of the subgroups (production flexibility, value-added sup-port and services, and cost). Finally, from Fig. 3, which shows the main effects for the individual attributes of the complete model, we see that the manufacturing tolerances attribute is the most important, ahead of the price.

In Fig. 2 we see that in general the German respondents attach more weight to most of the attributes, but that this does not hold for the price attribute as also shown in Table 1 with the cost category, and that this difference is most evident in the manufacturing tolerances attribute. From Fig. 3 we learn that even when we investigate the individual attributes, price is not the most important, but rather the manufacturing tolerances attribute (followed by the price, product range, and engineering consulting attributes). Thus, in the commodity raw material market, it is naturally very important to offer a low price, but this is definitely not the only important attribute. 

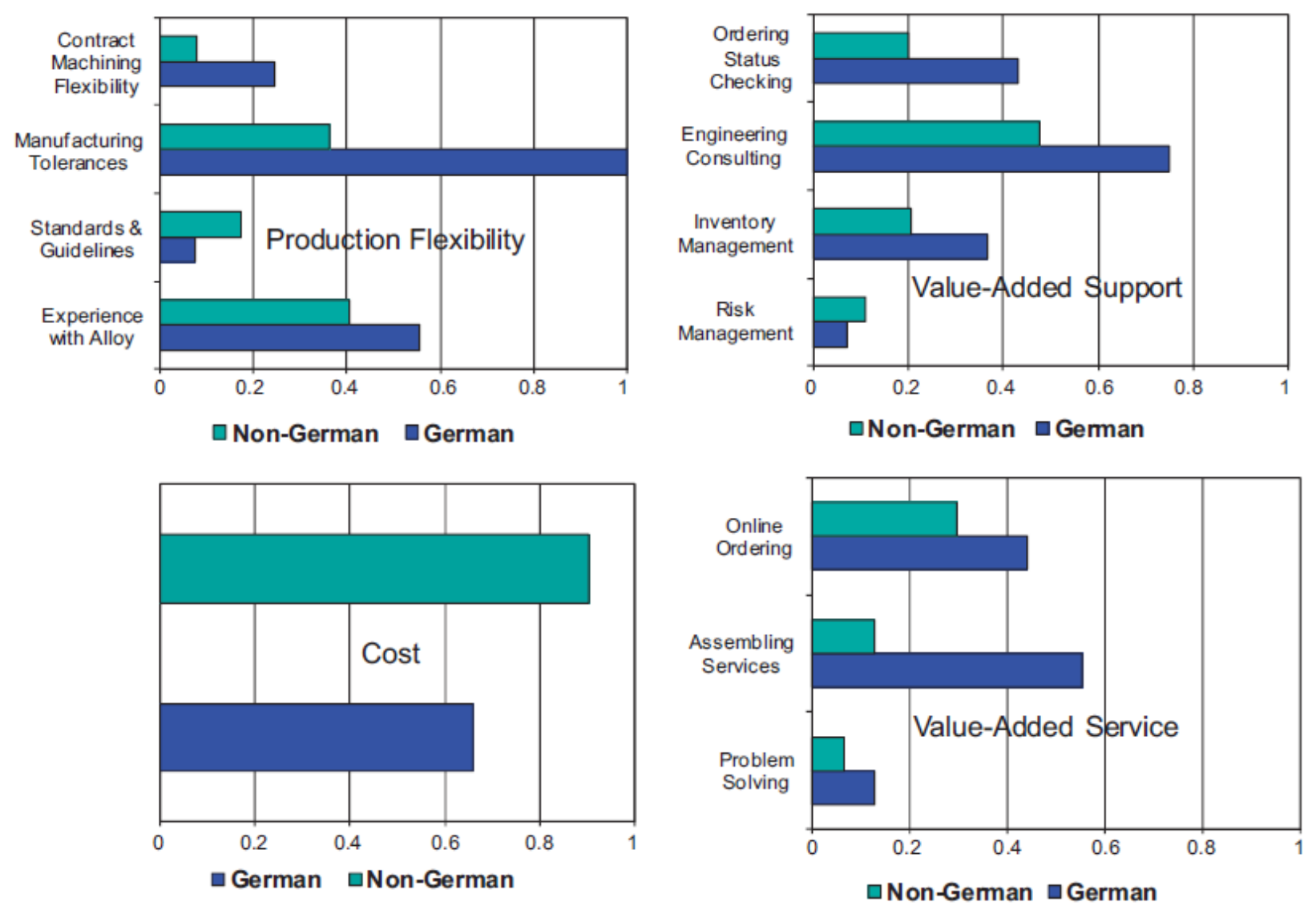

Fig. 2 Comparing relative main effects of the attributes within the production flexibility, valueadded support and services, and cost subgroups.

\section{Concluding Remarks}

Leading publications in business management emphasize the need for understanding manufacturing and supply chain related decisions and practices for improving the competitive position of a firm. Various publications argue that it is necessary for these managerial decisions and choices to be consistent with the corporate strategy for effective operations management. The objective of this research was to understand one strategic operating decision area: the supplier selection process. As more manufacturing organizations adopt extended-enterprise concepts, the role of supplier and supply chain management becomes even more important.

Our study was designed primarily to study how managers' trade-off among cost, valueadded, delivery performance, and flexibility attributes when choosing a supplier for major components and/or raw materials, given acceptable quality. The results presented in this paper have important implications for operations strategy and supply chain management research.

We found that overall the managers valued the suppliers' flexibility the most, and in particular the attributes of manufacturing tolerances, product ranges, acceptance of small orders, and expertise with the use of alloys. Flexibility was followed by the cost variable in 
importance; especially respondents from Italy (and to a somewhat lesser degree those from France and the UK) indicated that the price was very important in the supplier selection process.

Thus, our results do not only show which attributes are important in the supplier selection process, they also show a level of agreement with previous studies in cultural differences (Hofstede, 2003; Schroeder and Flynn, 2001). In this context it is interesting to note that although the Germans valued the cost subgroup as the least important out of the seven subgroups; the other respondents valued this attribute as the third most important overall.

Furthermore, our research shows some interesting differences with past research. First of all we used the DCA approach in an innovative way as we had our respondents choose between their current supplier and a hypothetical new one, a method to our knowledge never applied before in the supplier selection literature. Also, past literature mostly agrees that quality, cost and delivery performance are the most important variables when selecting a supplier (except for Verma and Pullman, 1998), while in our research the quality was assessed as "conforming to specifications" and therefore not part of the attributes. As a result, we found that flexibility was the most important variable overall, followed by cost and delivery performance.

\section{Directions for Future Research}

As in any empirical study we were faced with certain difficulties and limitations. Even though we have a multinational sample, the countries in our study were all in the same continent. We found some interesting differences across these cultures, and it would be very interesting to see whether these differences are even greater when different countries are sampled across continents. We also collected data in only one industry, so a possible extension could be to compare across industries. However, our approach seems to be the norm in this literature stream as we do not want the results to be diluted by sampling different industries. As a final note to managers at suppliers, we would like to point out that the value-added attributes used in this study seemed to be of small importance to the decision-makers at the manufacturers, with the possible exception of engineering consulting (refer to Fig. 3). We would therefore caution the suppliers against spending time and resources on these activities (providing risk and inventory management, and developing an online ordering support system for example), while the manufacturer is more interested in flexibility or a low price.

\section{References}

Amoako-Gyampah, K., Acquaah, M., 2008. Manufacturing strategy, competitive strategy and firm performance: An empirical study in a developing economy environment. International Journal of Production Economics 111 (2), 575-592.

Anderson, J.C., Cleveland, G., Schroeder, R.G., 1989. Operations strategy: A literature review. Journal of Operations Management 8 (2), 133-157. Ansari, A., Modarress, B., 1980. JIT 
purchasing as a quality and productivity center. International Journal of Production Research 26 (1), 19-26.

Ansari, A., Modarress, B., 1986. Just-in-time purchasing: Problems and solutions. Journal of Purchasing and Materials Management, 11-15.

Araz, C., Ozkarahan, I., 2007. Supplier evaluation and management system for strategic sourcing based on a new multicriteria sorting procedure. International Journal of Production Economics 106 (2), 585-606.

Bankar, R.D., Khoska, I.S., 1995. Economics of operations management: A research perspective. Journal of Operations Management 12, 423-435.

Barbarosoglu, G., Yazgac, T., 1997. An application of the analytic hierarchy process to the supplier selection problem. Production and Inventory Management Journal 38 (1), 1421.

Basnet, C., Leung, J.M.Y., 2005. Inventory lot-sizing with supplier selection. Computers \& Operations Research 32 (1), 1-14.

Ben-Akiva, M., Lerman, S.R., 1991. Discrete Choice Analysis. MIT Press, Cambridge, MA.

Bendoly, E., Donohue, K., Schultz, K.L., 2006. Behavior in operations management: assessing recent findings and revisiting old assumptions. Journal of Operations Management 24, 737-752.

Benton, W.C., Krajewski, L., 1990. Vendor performance and alternative manufacturing environments. Decision Sciences 21. Bernard, P., 1989. Managing vendor performance. Production and Inventory Management Journal, 1-7.

Bettman, J.R., Capon, N., Lutz, R.J., 1975. Multiattribute measurement models and multiattribute attitude theory: A test of construct validity. Journal of Consumer Research $1(4), 1-15$.

Bhutta, K.S., Huq, F., 2002. Supplier selection problem: A comparison of the total cost of ownership and analytical hierarchy process approaches. Supply Chain Management 7, 126.

Boyer, K.K., Lewis, M.W., 2002. Competitive priorities: Investigating the need for trade-offs in operations strategy. Production and Operations Management 11 (1), 9-20.

Boyer, K.K., Ward, P.T., Leong, G.K., 1996. Approaches to the factory of the future an empirical taxonomy. Journal of Operations Management 14 (4), 297-313.

Braglia, M., 2000. A quality assurance-oriented methodology for handling trade-offs in supplier selection. International Journal of Physical Distribution \& Logistics Management 30 (1/2), 96-111. 
Brewer, A.M., Button, K.J., Hensher, D.A., 2001. Handbook of Logistics and Supply Chain Management. Pergamon.

Browning, J.M., Zabriskie, N.B., Huellmantel, A.B., 1983. Strategic purchasing planning. Journal of Purchasing and Materials Management, 19-24.

Burton, T.T., 1988. JIT/Repetitive sourcing strategies: Tying the knot with your suppliers. Production and Inventory Management, 38-41.

Cakravastia, A., Takahashi, K., 2004. Integrated model for supplier selection and negotiation in a make-to-order environment. International Journal of Production Research 42 (21), 4457-4474.

Cardozo, R. N., Cagley, J. W., 1971. Experimental study of industrial buyer behavior. Journal of Marketing Research, 329-934.

Carter, C. R., Jennings, M. M., 2004. The role of purchasing incorporate social responsibility: A structural equation analysis. Journal of Business Logistics 25(1), 145-186.

Chan, F.T.S., 2003. Interactive selection model for supplier selection process: An analytical hierarchy process approach. International Journal of Production Research 41(15), 35493579.

Chan, F.T.S., Kumar, N., 2007. Global supplier development considering risk factors using fuzzy extended AHP - based approach. Omega 35 (4), 417-431.

Chan, F.T.S., Chan, H.K., 2004. Development of the supplier selection model-a case study in the advanced technology industry. Proceedings of the Institution of Mechanical Engineers Part B-Engineering Manufacture 218(12), 1807-1824.

Chapman, S.N., 1993. Just-in-time supplier inventory: An empirical implementation model. International Journal of Production Research 27(12), 1993-2007.

Chen, C.-T., Lin, C.-T., Huang, S.-F., 2006. A fuzzy approach for supplier evaluation and selection in supply chain management. International Journal of Production Economics 102(2), 289-301.

Choi, T.Y., Hartley, J.L., 1996. An exploration of supplier selection practices across the supply chain. Journal of Operations Management 14(4), 333-343.

Choy, K.L., Lee, W.B., Lo, V., 2003. An intelligent supplier relationship management system for selecting and bench marking suppliers. International Journal of Technology Management 26(7), 717-740.

Choy, K.L., Lee, W.B., Lau, H.C.W., Lu, D., Lo, V., 2004. Design of an intelligent supplier relationship management system for new product development. International Journal of Computer Integrated Manufacturing 17(8), 692-715. 
Crama, Y., Pascual, J.R., Torres, A., 2004. Optimal procurement decisions in the presence of total quantity discounts and alternative product recipes. European Journal of Operational Research 159(2), 364-378.

Degraeve, Z., Labro, E., Roodhooft, F., 2005. Constructing a total cost of ownership supplier selection methodology based on activity-based costing and mathematical programming. Accounting and Business Research 35(1), 3-27. Dempsey, W.A., 1978. Vendor selection and the buying process. Industrial Marketing Management 7,257-267.

Dickson, G.W., 1966. An analysis of vendor selection systems and decisions. Journal of Purchasing 2(1), 5-17.

Ding, X., Verma, R., Iqbal, Z., 2007. Self-service technology and online financial service choice. International Journal of Service Industry Management 18(3), 246-268.

Eltantawy, R.A., Sharland, A., Giunipero, L.C., 2003. The impact of cycle time on supplier selection and subsequent performance outcomes. Journal of Supply Chain Management 39(3), 4-12.

Fine, C., 1998. Clock Speed: Winning Industry Control in the Age of Temporary Advantage. Perseus Books, Reading, MA.

Flynn, B.B., Schroeder, R.G., Sakakibara, S., 1994. A frame work for quality management research and an associated measurement instrument. Journal of Operations Management 11,339-366.

Gonzàlez, M.E., Quesada, G., Mora Monge, C.A., 2004. Determining the importance of the supplier selection process in manufacturing: A case study. International Journal of Physical Distribution \& Logistics Management 34(6), 492-504.

Green, P.E., Krieger, A.M., 1996. Individualized hybrid models for conjoint analysis. Management Science 42(6), 850-867.

Green, P.E., Srinivasan, V., 1990. Conjoint analysis in marketing: New developments with implications for research and practice. Journal of Marketing 54(4), 3-19.

Guadagni, P.E., Little, J.D.C., 1983. A logit model of brand choice calibrated on scanner data. Marketing Science 2(2), 203-238.

Hahn, C.K., Pinto, P.A., Bragg, D.J., 1983. Just-in-time production and purchasing. Journal of Purchasing and Materials Management, 2-10.

Hall, D., Braithwaite, A., 2001. The development of thinking in supply chain and logistics management. In: Handbook of Logistics and Supply Chain Management.

Hanfield, R.B., Nichols Jr., E. L., 1999. Introduction to Supply Chain Management. Prentice-Hall, Upper Saddle River, NJ. 
Hayes, R.H., Wheelwright, S.C., 1984. Restoring our Competitive Edge: Competing through Manufacturing. Wiley, New York.

Hensher, D.A., Johnson, L.W., 1981. Applied Discrete-Choice Modelling. Halsted Press, New York.

Hirakubo, N., Kublin, M., 1998. The relative importance of supplier selection criteria: The case of electronic components. International Journal of Purchasing \& Materials Management $34(2), 19-24$.

Hofstede, G.H., 2003. Culture's Consequences: Comparing Values, Behaviors, Institutions and Organizations Across Nations. Sage, Beverley Hills, CA.

Huang, S.H., Keskar, H., 2007. Comprehensive and configurable metrics for supplier selection. International Journal of Production Economics 105 (2), 510-523.

Ittner, C.D., Larcker, D.F., 1999. Supplier selection, monitoring practices, and firm performance. Journal of Accounting \& Public Policy 18 (3), 253-281.

Jackson, G.C., 1983. Just-in-time production: Implications for logistics managers. Journal of Business Logistics 4 (2), 1-19.

Kamann, D.-J.F., Bakker, E.F., 2004. Changing supplier selection and relationship practices: A contagion process. Journal of Purchasing \& Supply Management 10 (2), 55.

Kannan, V.R., Tan, K.C., 2002. Supplier selection and assessment: Their impact on business performance. Journal of Supply Chain Management 38 (4), 11.

Kaplan, S., Sawhney, M., 2000. E-hubs: The new B2B marketplaces. Harvard Business Review May-June, 97-103.

Karmarkar, U.S., 1996. Integrative research in marketing and operations management. Journal of Marketing Research 33 (5), 125-133.

Karpak, B., Birsen, K., Rammohan, R., Kumcu, E., 1999. Multi-objective decision-making in supplier selection: An application of visual interactive goal programming. Journal of Applied Business Research 15 (2), 57-71.

Kraljic, P., 1983. Purchasing must become supply management. Harvard Business Review, 109117.

Lambert, D.M., Adams, R.J., 1997. Supplier selection criteria in the healthcare industry: A comparison of importance and performance. International Journal of Purchasing \& Materials Management 33 (1), 16-22.

Lancaster, K.J., 1966. A New Approach to Consumer Theory, The Journal of Political Economy. The University of Chicago Press. Li, S., 
Madhok, A., Plaschka, G., Verma, R., 2006. Supplier-switching inertia and competitive asymmetry: A demand-side perspective. Decision Sciences 37 (4), 547-576.

Liao, Z., Rittscher, J., 2007a. A multi-objective supplier selection model under stochastic demand conditions. International Journal of Production Economics 105 (1), 150-159.

Liao, Z., Rittscher, J., 2007b. Integration of supplier selection, procurement lot sizing and carrier selection under dynamic demand conditions. International Journal of Production Economics 107 (2), 502-510.

Lin, C., Chow, W.S., Madu, C.N., Kuei, C.-H., Yu, P.P., 2005. A structural equation model of supply chain quality management and organizational performance. International Journal of Production Economics 96 (3), 355-365.

Louviere, J.J., Hensher, D.A., Swait, J.D., 2000. Stated choice methods: analysis and applications. Cambridge University Press, UK.

Louviere, J.J., Woodworth, G., 1983. Design and analysis of simulated consumer choice or allocation experiments: An approach based on aggregate data. Journal of Marketing Research 20 (4), 350-367.

Louviere, J.J., Hensher, D.A., Swait, J.D., 2001. Stated Choice Methods: Analysis and Application. Cambridge University Press, London.

Lynch Jr., J.G., Marmorstein, H., Weigold, M.F., 1988. Choices from sets including remembered brands: Use of recalled attributes and prior overall evaluations. Journal of Consumer Research 15 (2), 169-184.

Masella, C., Rangone, A., 2000. A contingent approach to the design of vendor selection systems for different types of co-operative customer/supplier relationships. International Journal of Operations and Production Management 21 (1), 70-84.

McFadden, D., 1986. The choice theory approach to market research. Marketing Science 5 (4), 275-297.

Miller, J.G., Graham, M.B.W., Freeland, J.R., Hottenstein, M., Maister, D.H., Meredith, J., Schmenner, R.G., 1981. Production/operations management: Agenda for the 80s. Decision Sciences 12, 547-571.

Monczka, R.M., Giunipero, L.C., Reck, R.F., 1981. Perceived importance of supplier information. Journal of Purchasing and Materials Management, 21-29.

Mummalaneni, V., Dubas, K.M., 1996. Chinese purchasing managers' preferences and tradeoffs in supplier selection and performance. Industrial Marketing Management 25 (2), 115-124. 
Onesime, O., Conrad, T., Xu, X., Zhan, D., 2004. A decision support system for supplier selection. International Journal of Information Technology \& Decision Making 3 (3), 453-460.

Patton III, W.E., 1996. Use of human judgment models in industrial buyers' vendor selection decisions. Industrial Marketing Management 25 (2), 135-149.

PattonIII, W.E., 1997. Individual and joint decision-making in industrial vendor selection. Journal of Business Research 38(2), 115-122.

Pearn, W.L., Wu, C.-W., Lin, H.C., 2004. Procedure for supplier selection based on $C_{p m}$ applied to super twisted nematic liquid crystal display processes. International Journal of Production Research 42(13), 2719-2734.

Pearson, J.N., Ellram, L.M., 1995. Supplier selection and evaluation in small versus large electronics firms. Journal of Small Business Management 33(4), 53-65.

Petroni, A., Braglia, M., 2000. Vendor selection using principle components analysis. Journal of Supply Chain Management 36(2), 63-69.

Prahinski, C., Benton, W.C., 2004. Supplier evaluations: Communication strategies to improve supplier performance. Journal of Operations Management 22, 39-62.

Pullman, M.E., Moore, W.L., 1999. Optimal service design: Integrating marketing and operations perspectives. International Journal of Service Industry Management 10(2), 23-26.

Pullman, M.E., Verma, R., Goodale, J.C., 2001. Service design and operations strategy formulation in multicultural markets. Journal of Operations Management 19(2), 239254.

Robb, J.D., Bin, X., Tiru, A., 2008. Supply chain and operations practice and performance in Chinese furniture manufacturing. International Journal of Production Economics 112 (2), 683-699.

Roodhooft, F., Konings, J., 1997. Vendor selection and evaluation. European Journal of Operational Research 96 (1), 97-102.

Rosenthal, E., Zydiak, J., 1995. Vendor selection with bundling. Decision Sciences 26 (1), 35-149.

Sarkis, J., Semple, J., 1999. Vendor selection with bundling: A comment. Decision Sciences 30 (1), 265-271.

Sarkis, J., Talluri, S., 2002. A model for strategic supplier selection. The Journal of Supply Chain Management 38 (1), 18-28.

Schroeder, R.G., Flynn, B.B., 2001. High Performance Manufacturing: Global Perspectives. Wiley, New York. 
Sharland, A., Eltantawy, R.A., Giunipero, L.C., 2003. The impact of cycle time on supplier selection and subsequent performance outcomes. Journal of Supply Chain Management $39(3), 4$.

Sheth, J.N., 1973. A model for industrial buyer behavior. Journal of Marketing, 50-56.

Simchi-Levi, D., Kaminsky, P., Simchi-Levi, E., 2000. Designing and Managing the Supply Chain. McGraw-Hill, Boston, MA.

Swait, J., Louviere, J.J., 1993. The role of the scale parameter in the estimation and comparison of multinomial logit models. Journal of Marketing Research 30, 305-314.

Swift, C.O., 1995. Preferences for single sourcing and supplier selection criteria. Journal of Business Research 32 (2), 105-111.

Talluri, S., Narasimhan, R., Nari, A., 2006. Vendor performance with supply risk: A chanceconstrained DEA approach. International Journal of Production Economics 100 (2), 258261.

Treleven, M., 1987. Single sourcing: A management tool for the quality supplier. Journal of Purchasing and Materials Management, 19-24.

Tseng, Y.-J., Lin, Y.-H., 2005. A model for supplier selection and tasks assignment. Journal of American Academy of Business Cambridge 6 (2), 197-207.

Valluri, A., Croson, D.C., 2005. Agent learning in supplier selection models. Decision Support Systems 39 (2), 219-240.

Verma, R., Pullman, M.E., 1998. An analysis of the supplier selection process. Omega 26 (6), 739-750.

Verma, R., Thompson, G.M., Louviere, J.J., 1999. Configuring service operations in accordance with customer needs and preferences. Journal of Service Research 1 (3), 262-274.

Verma, R., Thompson, G.M., Moore, W.L., Louviere, J.J., 2001. Effective design of products/services: An approach based on integration of marketing and operations management decisions. Decision Sciences 32 (1), 165-193.

Vickery, S.K., Dorge, C., Markland, R.E., 1993. Production competence and business strategy: Do they affect business performance? Decision Sciences 24 (2), 435-455.

Victorino, L., Verma, R., Plaschka, G., Dev, C., 2005. Service innovation and customer choices in the hospitality industry. Managing Service Quality 15(6).

Vokurka, R.J., Choobineh, J., 1996. A prototype expert system for the evaluation and selection of potential suppliers. International Journal of Operations \& Production Management 16 (2), 106-127. 
Vonderembse, M.A., Tracey, M., 1999. The impact of supplier selection criteria and supplier involvement on manufacturing performance. Journal of Supply Chain Management 35 (3), 33-39.

Wagner, J., Ettenson, R., Parrish, J., 1989. Vendor selection among retail buyers: An Analysis by merchandise division. Journal of Retailing 65 (1), 58-77.

Wang, G., Huang, S.H., Dismukes, J.P., 2004. Product-driven supply chain selection using integrated multi-criteria decision-making methodology. International Journal of Production Economics 91 (1), 1-15.

Weber, C.A., Current, J.R., 1993. A mulitobjective approach to vendor selection. European Journal of Operational Research 68, 173-184.

Weber, C.A., Current, J.R., Benton, W.C., 1991. Vendor selection criteria and methods. European Journal of Operational Research 50, 2-18.

Wilson, E.J., 1994. The relative importance of supplier selection criteria: A review and update. International Journal of Purchasing \& Materials Management 30 (3), 35-41.

Yan, J., Chaudhry, P.E., Chaudhry, S.S., 2003. A model of a decision support system based on case-based reasoning for third-party logistics evaluation. Expert Systems 20 (4).

Yano, C.A., Dobson, G., Profit optimizing product line design, selection and pricing with manufacturing cost considerations: a survey, inProduct Variety Management: Research Advances, Kluwer Academic Publisher, November 1998, 145-176. 